\title{
Impact of Parental Separation on the Self-Esteem of in-School Adolescents in Nigeria
}

\section{Mulikat Ladi AbdulQadir Mustapha}

$\mathrm{PhD}$, Department of Counsellor Education, Faculty of Education, University of Ilorin, Ilorin, Nigeria, mustapha.mla@unilorin.edu.ng \& ladiuthman9150@gmail.com

\section{Deborah Odediran}

Department of Counsellor Education, Faculty of Education, University of Ilorin, Ilorin, Nigeria

Nigerian adolescents are facing increasing rate of parental separation, which is affecting their overall development, including good mental health. Various studies have examined the impact of parental separation on the self-esteem of adolescents. Outcomes of such studies are elaborate, complex and intricate. The present inquiry re-examined how parental separation influence in-school adolescents self-esteem in Ilorin, Nigeria. The model adopted for this research is descriptive survey, using stratified random selection procedure across six schools in Ilorin metropolis, with the purpose of re-considering how gender, age and school type moderate the impact that parental separation has on the self-esteem of the in-school adolescents. Copies of the adapted form of Rosenberg Self-Esteem scale were administered to 300 students from separated parents. The t-test and Analysis of Variance were used to analyse the hypotheses. It was discovered that about three-quarter (216 of 300) of the participants scored below 50 (have low self-esteem), thus parental detachment has effect on the self-esteem of both male and female in-school adolescents negatively. However, the influence that parental detachment has on inschool adolescents' self-esteem varies on the basis of age and school type.

Keywords: in-school adolescents, parental separation, self-esteem, secondary schools, Nigeria

\section{INTRODUCTION}

Marriage has been described as the coming together of a man and a woman to form a family in order to meet essential security, enduring care and companionship (Kolander, Ballard \& Chandler, 2009). From this definition, it could be inferred that marriage assists man to meet his needs of companionship, child procreation among others. A marital relationship that serves the purpose of companionship is characterized with 
couples living together to establish a family. Marriage within African traditions and from religious perspectives is the approved means of establishing a family (Oniye, 2016), thus providing the avenue for the overall development of the children. Family constitutes the building block of societies in the world (Wilson, 2013) and forms the backbone of socio-economic and political development (Carmicheal, Dilli, Zanden, 2016). However, various factors such as conflicts, pressures of life, sophistication, sudden rise in the acceptance of western culture, negligence of one of the couple or both of them to exercise patience or perform their marital expectations, the socio-economic situations in Nigeria, urbanization, industrialization, ethnicity, religion and family disorganization among other factors are threatening the likelihood of parents living together (Adegoke, 2010; Akinlabi \& Olatunji, 2013).

Adegoke and Esere (1998) had earlier noted the unprecedented increase in the rate of conflicts among married couples. When conflicts arise and they are not settled rationally by couples, it may lead to separation (Hudson, 2014) which has now become a common occurrence (Rosnati, 2014) and a source of concern to all stakeholders in the institution of marriage. Consequently, the nobility of marriage which calls for mutual love, coexistence and harmony is gradually fading away. Laoye-Balogun (2015) has decried the astronomical increase in the rate of divorce in Nigeria as evidenced by the higher number of divorce petitions filed before the courts across Nigeria, with the children as the most affected group by such dissolutions. Separation/divorce is a legitimate accord by which husband and wife opt not to dwell together, resulting in the removal of children from one or both of the parents. Separation frees parents from the burden of child-rearing (Caye, 1996; Ahiaoma, 2013; Akinlabi \& Olatunji, 2013).

Irvin (2012) stated that it is no longer news that parental separation impacts approximately fifty percent of current marriages throughout the United States. Statistics revealed that forty-three percent of American children are been raised without their fathers, while seventy-five percent of children with divorced parents live with their mothers (Irvin, 2012). This change in family structure is affecting members of the household, especially children and the adolescents as well as the society at large.

Adolescence as a transitional stage between childhood and adulthood is a crucial phase during which adolescents are expected to achieve a number of developmental tasks (Oyinloye, 2001). At this stage, adolescents require parental support and encouragement to achieve these developmental tasks. Consequently, parental support plays an integral part in fostering a healthy development for adolescents. When adolescent grows up in an intact home, both parents contribute their quota towards his/her development. On the other hand, parental separation can negatively impact young children's psychological adjustment, behaviour, social ability, self-esteem, and academic achievement, which can persist throughout adulthood (Amato, 2001; Baker \& Ben-Ami, 2011; Bing et al., 2009; Clarke-Stewart, Vandell, McCartney, Owen, \& Booth, 2000; Short, 2002). Similarly, Huitt (2011) noted that children and adolescents who experience the divorce of their parents have higher rates of depressed mood, lower self-esteem, and emotional distress. 
Self-esteem is described as the adolescents' personal appraisal of his or her value (Orth \& Robins, 2014). It can be viewed as an array of thoughts, ideas and principles that influences an individual when facing the world. It includes beliefs as to whether he or she anticipates achievement or disappointment, the extent of struggling, whether failure at a task will be distressing and whether the difficult experience will strengthen him or her. Self-esteem depicts whether an individual has a constructive or non-constructive view of self. It involves the practices of living consciously with self-recognition, selfresponsibility, self-confidence, focused living and that of personal integrity (Branden, 1994)

Alexander (2001) views self-esteem as a condition in which individual unconditionally appreciates his or her positive and negative abilities in its maximum state, and as a set of indicator for mental well-being. An individual's self-esteem develops from his or her internal perception, experiences and external information from others (Sternke, 2010) and could be high or low. Sherman (2015) describes high self-esteem as a healthy awareness of the self that logically incorporate limitations but is not bitterly critical of them.

In the word of Coppersmith (1984), low self-esteem individuals are characterised with a picture of discouragement and depression. They feel isolated, unlovable, incapable of expressing or defending themselves and too weak to confront or overcome their deficiencies. In the presence of a social group, at school or elsewhere, they linger in the darkness, passive rather than active, vulnerable to reproach, uncomfortable, engrossed with an inner problem. The low self-esteem individuals are more likely to be unhappy, discouraged, quick-tempered, and weak academically. This means that a person with low self-esteem lacks a global sense of self-worth (Gonzalez-Mena, 1993). Majority (76.4\%) of the Nigerian adolescents have been found to have high self-esteem (Chinawa, Obu, Manyike, Obi, Israel, Chinawa, 2015), though, parents' marital status was not considered by these researchers. Results of the study however noted age and gender differences. Several types of researches (Veenstra, et al., 2006; Sentse, et al., 2011;Huitt, 2011; Alami, et. al. 2014; Mekonen, 2014; Kithela, 2016) have been carried out on consequences of parental separation as it affects the academic and psychological development of in-school adolescents.

Many of these studies revealed that parental separation impacts children's self-esteem negatively (Ahiaoma, 2013; Alami et al, 2014; Huitt, 2011; Marks, Jun \& Song, 2007; Moschion, 2015; Santrock, 2014). Other studies (Bing, Nelson III \& Welsolowski, 2009; Ross \& Miller, 2009; Kevorkian, 2010; Sentse, Ormel, Veenstra, Virhulst \& Oldehinkel, 2011) emphasised that parental separation might not be responsible for adolescents' low self-esteem. for instance, a study conducted by Sentse, Ormel, Veenstra, Virhulst and Oldehinkel (2011), on the probable impact of parental detachment in the early stage of adolescence on adolescent's externalising and internalising. It was reported that separation may only have an effect under certain conditions. Child temperament (effortful control and anxiety) regulates the effect of parental detachment on particular mental health realms. 
Veenstra, Lindenberg, Oldehinkel, De Winter and Ormel (2006) in a study conducted on the influence of parenting on anti-social behaviour of adolescents, reported that antisocial behaviour can be exacerbated or triggered off by social experiences and individuals processing of these experiences. The study focused on the interaction between temperament, perceived parenting, socioeconomic status and gender in relation to the anti-social behaviour of adolescents. All parenting and temperament factors were significantly associated with anti-social behaviour. Socio-Economic Status (SES) was only a related factor to anti-social behaviour among adolescents with a low level of effortful control or a high level of frustration due to parental separation.

The impact of parental separation on self-esteem of adolescents could be premised on Attachment theory of Bowlby (1969, 1973, $1979 \&$ \& 1988). The theory proposed that parental separation impact on adolescents' self-esteem in two major ways. Firstly, parental separation poses attachment-related problems. The theory posits that parental separation reduces the adolescent's self-reliance in who and where his/her loved figure is; the perception of his acceptance before the important figure as well as the availability, approachability and subtle reaction of attachment figure, thus impacting the adolescent's self-esteem. Residing separately in which access to parent becomes unsubstantiated may weaken adolescent's feeling of security (Page \& Bretherton, 2001; Feeney \& Monin, 2008). Secondly, the separation-linked tensions which separated parent is going through often inhibit his/her ability to meet the children's need for safety and security (Page \& Bretherton, 2001). Such separation-linked tensions identified include financial adversity, change in residence, changing school and parental remarriage (Amato, 2000; Feeney \& Monin, 2008).

From the prior studies, it could be deduced that the family as the basic unit of the society may build or impair the self-esteem of adolescents. It has also been stressed that the extent to which parental separation affects the self-esteem of adolescents could be moderated by other precipitating factors and individual differences of adolescents. These factors include age, gender and types of school been attended by the children or adolescents from separated parents. Furthermore, significant others (grandparents, peers) in the social milieu of adolescents could also have a substantial influence on the self-esteem of adolescents.

Findings of studies regarding age and gender differences vary and seem inconclusive. While some revealed age and gender differences, others found no significant difference. Bleidorn, Denissen, Gebauer, Arslen, Rentflow, Potter and Gosling (2015) revealed that individual's self-esteem increases with age, particularly from late adolescence to middle adulthood. The results also indicated that male have higher self-esteem than female. The researchers however reiterated that variation could occur on the basis of culture, socioeconomic, sociodemographic, gender-equality and cultural value indicators. Chinawa et al (2015) found the self-esteem of adolescents between the ages of 14 and 17 years to be positive while older adolescents (18-19 years) are largely with low selfesteem. However, Sahin et al (2013) found no significant age difference in the selfesteem of Turkish adolescents, though; the studies were not comparing self-esteem of adolescents from separated parents. 
Outcomes of empirical inquiries regarding gender differences are conflicting. Researchers (Cakici, 2010; Cevik \& Atici, 2009; Gelbal et al, 2010; Kahyaoglu, 2010; Secer et al 2012) found no significant gender difference in the self-esteem of adolescents. Other studies indicated that self-esteem scores of the females are greater than those of the male respondents (Karakas, 2012; Oner-Altiok, Ek \& Koruklu, 2010). Conversely, researchers (Bleidorn et al., 2015; Chinawa et al., 2015) revealed that female respondents scored lower on self-esteem scale than males. In a related study, Sirvanli-Ozen (2005) had earlier found that young women who have experienced parental separation do have more relationship problems than young males. There is therefore the need to reconsider the moderating variables of age and gender especially as they impact self-esteem of adolescents from separated parents amidst the conflicting outcomes of prior inquiries. Kithela (2016) studied the relationship between school type and secondary school students' self-esteem, academic achievement and career aspirations in Nairobi, Kenya. The study found a significant relationship between school type and students' self-esteem. In this inquiry, effort was made to see whether school type would moderate the impact of parental detachment on adolescents' self-esteem.

Although previous findings documented devastating consequences of parental separation on children's wellbeing, the need for this inquiry is premised on some assumptions. The stigma attached to parental separation especially divorce has drastically reduced in Nigerian societies due to high rate of divorce cases as well as changes in perception of people regarding divorce, it is believed that this will reduce the impact that parental separation has on the wellbeing of the adolescents. Also, the increasing participation of women in economic activities and reduction in their economic dependency on men folk would probably reduce the negative impact of parental separation on children and adolescents as against previous findings. Thus, it is against this background that the researchers re-explored how parental separation impact in-school adolescents' self-esteem to advance existing literature. Particularly, the study:

1. Inquires the influence of parental detachment on the self-esteem of in-school adolescents from separated homes in Ilorin, Nigeria

2. Determines the moderating effect of gender, age and school type on the influence that parental detachment has on the in-school adolescents' self-esteem.

\section{Research Questions}

The following research questions were raised to guide the conduct of this study:

1. What is the impact of parental separation on the self-esteem of in-school adolescents in Ilorin, Nigeria?

2. Is there any gender difference in the impact of parental separation on the in-school adolescents' self- esteem?

3. Is there any age difference in the impact of parental separation on the in-school adolescents' self-esteem?

4. Is there any difference in the impact of parental separation on the in-school adolescents' self-esteem on the basis of school type?

International Journal of Instruction, January2019 • Vol.12, No.1 


\begin{abstract}
METHOD
This study is a quantitative research; therefore, the research design utilised for the study is the descriptive research design. The independent variable considered, is parental separation, while the dependent variable is self-esteem. Precisely, respondents were those in-school adolescents from separated or single-parent homes identified by the school counsellors. All in-school adolescents from separated homes in secondary schools within Ilorin metropolis constituted the population for this study. Stratified random sampling technique was employed to choose six secondary schools utilising the strata of school types and school location to give an adequate representation of the three local Government areas that constitute the study area.
\end{abstract}

Four public and two private schools were selected randomly. All in-school adolescents from separated homes were purposively selected by the school counsellors who have this information in the students' cumulative record folder. Data for the study were collected using self-report questionnaire titled "impact of parental separation on the selfesteem of adolescents Questionnaire" (IPSSEA) which was key device employed for data collection. IPSSA was an adapted questionnaire structured based on Rosenberg's Self-Esteem Scale: a self-report appraisal of global self-worth developed by Morris Rosenberg in 1965. The choice of the scale is based on its strong hypothetical qualities like succinctness, thoroughness and relevance for use with secondary school students (Chu, 1988; Sahin, et al., 2013). It has wide use in many studies both within and outside Nigeria (e.g. Gray-Little et al., 1997; Pullmann \& Allik, 2000, Martin-Albo et al., 2007; Elion, et al., 2012;.Dennis \& Oluwatelure, 2016; Okwaraji et al. 2016; Egwurugwu et al., 2017) that has proven its validity and reliability. The scale is said to be adapted due to changes in some of its features. For instance, original scale has 10 items with five items positively worded and remaining five negatively worded, the adapted version however has 20 items. The measure has two segments: the first segment covers items on respondents' biographical data like age, gender and school type, the second segment contains 20 items to uncover respondents' appraisal of their self-esteem using a fourpoint scale from strongly agree to strongly disagree. Content validity of the IPSSA was ascertained by some experts in the Department of Counsellor Education, University of Ilorin, Nigeria. For the reliability, test re-test procedure was employed and the result yielded coefficient of 0.67 .

\title{
Procedure for Data collection
}

Permission of the school principals was sought through the introductory letter, discussions were held with school counsellors in the various schools to explain the nature of the research and for identification of students from separated families. Thereafter, the consent of the identified students who were 18 years and above was sought (for those below 18 years, the consent of their parents were sought) and the instrument was administered to those who willingly volunteered to take part. One of the researchers was at the school to make needed clarifications, completed forms were retrieved back immediately, thus, facilitated $100 \%$ return rate. 
The scoring of the responses was based on a 4-point Likert-type scale. The first 10 items were positively worded and highest score for respondent was 40, while the last 10 items were negatively stated and reverse scored. The highest possible score was 80 , lowest 20 with mid-point of 30, the cut-off score was 50. A score of 50 and above depicted high self-esteem, while a score below 50 depicted low self-esteem.

The statistical method adopted for the analyses of data collected were descriptive and inferential statistics at 0.05 alpha levels. Specifically, hypotheses 1 and 3 were tested using t-test statistical tool while hypothesis 2 was tested using Analysis of Variance (ANOVA). Duncan Multiple Range Test was used for post-hoc analysis to ascertain the course of significant difference.

\section{FINDINGS}

This section presents the results of data obtained on the respondents using descriptive analysis (percentages) and inferential statistics of t-test and Analysis of Variance

Table1

Percentage Distribution of Respondents Based on Age, Gender and School type

\begin{tabular}{lll}
\hline Variables & Frequency & Percentage \\
\hline Age & & \\
$10-14$ years old & 159 & 53.0 \\
15-19 years old & 133 & 44.3 \\
20 years \& above & 008 & 2.7 \\
Total & 300 & 100 \\
Gender & & \\
Female & 165 & 55.0 \\
$\quad$ Male & 135 & 45.0 \\
$\quad$ Total & 300 & 100 \\
School type & & \\
Private & 100 & 33.3 \\
Public & 200 & 66.7 \\
Total & 300 & 100 \\
\hline
\end{tabular}

Table 1 shows the distribution of respondents by age, gender and school type.

To determine whether parental separation impacts self-esteem of in-school adolescents, descriptive analysis was carried out. Table 2 depicts the percentage of respondents that reported high self-esteem $(84,27 \%)$ as well as low self-esteem $(216,73 \%)$. Out of the three hundred in-school adolescents from separated parents, $216(73 \%)$ experienced low self-esteem compared to $84(27 \%)$ that reported having high self-esteem. This shows that parental separation impact adolescents' self-esteem negatively

Table 2

Impact of parental separation on the self-esteem of in-school adolescents

\begin{tabular}{llll}
\hline Self-esteem & Score & Frequency & Percentage \\
\hline High & $51-80$ & 84 & $27 \%$ \\
Low & Below 50 & 216 & $73 \%$ \\
\hline
\end{tabular}

International Journal of Instruction, January2019 • Vol.12, No.1 
To test the three hypotheses formulated and consider whether the variables of age, gender and school type affect the impact that parental separation has on in-school adolescents' self-esteem, t-test and ANOVA statistical methods were used at 0.05 significant levels.

Hypothesis One: There is no significant gender difference in the influence of parental detachment on in-school adolescents' self-esteem

Table 3

Mean, Standard Deviation and t-value of the influence of parental separation on in school adolescents' self-esteem on the basis of gender.

\begin{tabular}{llllllll}
\hline Gender & $\mathrm{N}$ & Mean & SD & Df & cal. t-value & crit. t-value & Sig \\
\hline Male & 165 & 46.48 & 9.08 & 298 & 0.26 & 1.96 & .188 \\
Female & 135 & 46.51 & 8.37 & & & & \\
\hline
\end{tabular}

Table 3 shows the significant value of 0.188 which is greater than $(0.05)$. Since the significant value is more than the alpha level of significance, thus, the hypothesis is accepted. This indicates that there is no significant difference in the impact of parental separation on in-school adolescents' self-esteem on the basis of gender.

Hypothesis Two: There is no significant age difference in the influence of parental detachment on in-school adolescents' self-esteem.

Table 4

Analysis of Variance (ANOVA) depicting the influence of parental detachment on the self-esteem ofin-school adolescents on the basis of their age

\begin{tabular}{lllllll}
\hline Source & df & SS & Mean Square & Cal. F-ratio & Crit. F-ratio & Sig. \\
\hline Between Groups & 2 & 1205.065 & 602.53 & & & \\
Within Groups & 297 & 21721.932 & 731.13 & $* 8.23$ & 3.00 & .001 \\
Total & 299 & 22926.997 & & & & \\
\hline
\end{tabular}

*significant @ 0.05 alpha level

Table 4 shows that the significant F-value of 0.001 is less than 0.05 . Since the significant F-value is less than the alpha level of significance, the hypothesis which stated that there is no significant age difference in the influence that parental segregation has on in-school adolescents' self-esteem is therefore rejected. Hence, the age of the inschool adolescents has significantly modified the influence that parental separation has on their self-esteem.

In order to determine the mean value(s) that caused the significant difference observed in the ANOVA results of Table 4, the Duncan Multiple Range Test (DMRT) was used as a post-hoc test. The results of the DMRT procedure are displayed in Table 5. 
Table 5

Duncan's Multiple Range Test (DMRT) showing the influence of parental detachment on the self-esteem of in-school adolescents on the basis of their age

\begin{tabular}{llcll}
\hline Group & Year & $\mathrm{N}$ & Means & Duncan Groupings \\
\hline 1 & 20 years \& above & 8 & 57.75 & $\mathrm{~A}$ \\
2 & 10-14 years & 159 & 46.87 & $\mathrm{~B}$ \\
3 & $15-19$ years & 133 & 45.37 & $\mathrm{C}$ \\
\hline
\end{tabular}

Table 5 showed the Duncan Multiple Range Test indicating the significant difference noted in the ANOVA on Table 4. Group 2 with a mean score of 46.87 differed from Group 3 with a mean score of 45.37 but significantly differed from Group 1 with a mean score of 57.75. All the groups differed from one another but the significant difference noted was as a result of the mean of Group 1, hence the significant difference noted in the ANOVA on Table 4 was brought about by respondents between the ages of 20 years old and above, therefore, the hypothesis is rejected.

Hypothesis Three: There is no significant difference in the impacts of parental separation on the self-esteem of in-school adolescents on the basis of school type

Table 6

Mean, Standard Deviation and t-value on the impact of parental separation on the selfesteem of $\mathrm{i}$ school adolescents on the basis of school type

\begin{tabular}{llllllll}
\hline School Type & N & Mean & SD & df & cal. t-value & crit. t-value & Sig \\
\hline Private & 100 & 48.09 & 7.615 & 298 & $* 2.243$ & 1.96 & .047 \\
Public & 200 & 45.70 & 9.189 & & & &
\end{tabular}

*significant @0.05 alpha level

Table 6 shows the significant t-value of 0.04 is less than 0.05 . Since the significant $t-$ value is less than the alpha level of significance, the hypothesis is rejected. Hence, there is a significant difference in the impact of parental separation on the self-esteem of inschool adolescents on the basis of school type.

\section{DISCUSSION}

In line with earlier studies on consequences of divorce/separation on child development, it was proposed that parental separation would significantly impact adolescents' selfesteem. The outcome of this study reconfirmed that parental separation negatively impacts adolescents' self-esteem. The rationale for this outcome could be premised on the fact that children, as well as young adolescents, require care, support and love from parents and significant others to develop holistically. In a situation where parents who are to offer a nurturing environment of attention, encouragement and love for the children especially at a critical stage of their development (adolescence) are separated, the adolescents may not meet this psychological need thereby jeopardising their emotional securities and self-esteem. The findings of this study corroborate previous research findings (Alami et al, 2014; Baker \& Ben-Ami, 2011; Huitt, 2011; Bing, et.al. 2009; Santrock, 2011). Alami, Khosravan and Hosseni (2014) found significant difference in the self-esteem score of adolescents from two-parent and single-parent 
families. Baker and Ben-Amin (2011) maintained that parental separation has farreaching effects on the self-esteem of the children regardless of their stage of development amidst other psychological deficits. Parental separation posits human being at risk for psychological and physical intricacies. Consequently, adolescents also get affected negatively by parental separation. In addition, parental separation or divorce is associated with academic difficulties, including lower grades and prematurely dropping out of school, and greater disruptive behaviours (e.g., being oppositional with authority figures, getting into fights, stealing, using and abusing alcohol and illegal drugs). Thus, Children and adolescents who experience the separation of their parents also have higher rates of depressed mood, lower self-esteem, and emotional distress (Amato, 2010; Lansford, 2009).

The t-test analysis and Analysis of Variance were conducted to examine the significant differences existing in the moderating variables (gender, school type and age) as they modify the influence of parental detachment on the adolescents' self-esteem.

Hypothesis one posits that gender would not significantly modify the influence that parental detachment has on the self-esteem of in-school adolescents. The outcome of the statistical analysis indicated no significant difference in the impact of parental separation on the self-esteem of both male and female in-school adolescents $(p>0.18)$. This implies that gender does not significantly affect the impact of parental separation on adolescents' self-esteem.

The reasons for the outcome could be that both male and female in-school adolescents from separated homes required parental support and encouragement necessary to foster healthy psychological development, the two parents have significant roles to play in the emotional security of their children regardless of their gender. Similarly, parenting tasks could be stressful and inadequate when a single parent had to bear the tasks singly and the consequent effects not limited to a specific gender among the children. The outcome is harmonious with prior research outcomes that have revealed negative effects of parental separation on the self-esteem of both male and female children. Amato (2001); Baker and Ben-Ami (2011), Bing et.al (2009), Cohen, Kasen, Chen, Hartmark, and Gordon (2003) had earlier indicated that parental separation places both male and female at chances for psychological and physical adversities. However, Mullen (2013) found gender differences in the self-esteem of adolescents from a single parent, step parent and intact families. Watkins, Dong and Xia (1997) also found a gender difference in some specific areas of self-esteem, such as in physical abilities, reading, school subscales and peer relations of Chinese children; though the study did not focus on children from separated families. The self-esteem scale employed by the later researchers differed.

Significant differences were noted on the bases of age and school type $(p<0.01, p<$ 0.04 ). Age could be significant in the development of self-esteem, adolescents who are 20 years and above could have secured strong attachment with peers which is a form of social support that also boost self-esteem (Feeney \& Monin, 2008). Similarly, an older adolescent could have been able to explore and gain self-competency in some areas of development which could have lessened the influence of parental detachment on their 
self-esteem compared to those below that age. It is also possible that they have been able to develop a sense of autonomy thereby reducing the negative effects of parental separation on their self-esteem. It is also possible that the older adolescents have grown up before the separation of the parent as earlier observed by previous studies. Moschion (2015) had earlier observed that adolescent's age at parental separation affects their future behaviour. Moschion, (2015) observed a contributory impact of parental segregation on entry into homelessness. Conditional on family and individual characteristics such as child age at parental separation in relation to his/her gender. Many studies showed that regardless of age; parental separation affects individuals throughout their life (Amato, 2001; Bing, Nelson III, \& Wesolowski, 2009; Ross \& Miller, 2009). Parental separation is distressing. It is distressing for parents, for children, and for intimate friends and relations. Individuals react to discomfort inversely based on their personality and their stage of life. For studies that found no age difference in the impact of separation on individuals involved, they are probably not on the selfesteem of adolescents.

Mekonen (2014) asserted that adolescents in private schools have higher self-esteem and self-concept than those in Government-owned schools. Kithela (2016) found significant relationship between school types and adolescents' self-esteem. Also, the California State Department (1990) had earlier indicated that schools that feature self-esteem as a clearly stated component of their goals, policies, and practices are more successful academically as well as in developing healthy self-esteem, thus, the findings of this study is in line with previous findings. The reason for the difference in the self-esteem of in-school adolescents from separated homes attending private and public schools could be due to the fact that majority of students in private secondary schools in Ilorin metropolis are from middle-class parents. The socioeconomic class of the separated parents could have been responsible for the variation in the self-esteem of the students who are from separated homes. Also, students from private schools have better selfperception than those from public schools.

\section{CONCLUSION AND RECOMMENDATION}

From the results of this study, it is affirmed that parental separation impacts adolescents' self-esteem negatively. It was also disclosed that age and school type of adolescents from separated parents significantly impact their self-esteem, however, the gender of the adolescents did not significantly determine the impact of parental separation on the selfesteem of these adolescents.

The outcomes of this inquiry have implications for stakeholders in marriage institutions and childcare services. There is need to intensify efforts in the prevention of parental separation through policies and conducive environment that foster marital stability. Marriage and Family counsellors should enlighten prospective couples and married adults on how various marital status impact children and adults' wellbeing. Such enlightenment could inform married adults on the need to take responsibility in promoting the type of union that will impact positively on family members' wellbeing. 
The findings also have implication for school counselling. It is essential to develop strategies for improving self-esteem of adolescents from separated homes especially the younger ones. School counsellors should assist all in-school adolescents from separated parents regardless of their gender. Counsellors in both private and public schools need to focus attention in assisting adolescents from separated parents develop positive and healthy self-esteem, though those in government owned schools require intensified efforts.

This inquiry utilised direct approach in its conduct and did not compare the adolescents from intact homes to determine if other factors aside parental separation are responsible for the low self-esteem. The measure administered did not inquire the age of adolescents at the time of parental separation which had earlier been noted to play down the impact of parental separation on the children's wellbeing. The nature of parent-child interaction was not considered to posit how it could moderate the impact of parental separation on adolescents' self-esteem. The study is cross sectional and deficient in longitudinal viewpoint. Regardless of these weaknesses, this inquiry has advanced literature on the impact of parental separation on in-school adolescents' self-esteem.

Future inquiries could probe the self-esteem of adolescents from varying family structure using longitudinal approach. The nature of the parental interaction could also be observed in relation to how it regulates the impact of parental separation on adolescents' self-esteem.

It was discovered in the study that the number of students from separated families is quite significant and increasing as the days go by, thus it is recommended that school counsellors should enlighten parents on the impacts of parental separation on adolescents' self-esteem. This in line with enlightenment on effects of divorce on children's development might discourage parental separation. School counsellors should identify and assist adolescents from separated families to develop healthy self-esteem regardless of their status through the inclusion of self-esteem development as part of School guidance programmes especially at public secondary schools though it should not be limited to them. Also, counsellors are to organize workshops for separated parents on how to prevent their children from the negative impacts of separation. 


\section{REFERENCES}

Adegoke, A.A. \& Esere, M.O. (1998).Sources of Stress and Coping Strategies among Divorcees in Ilorin Metropolis. The Counsellor, Journal of the Counselling Association of Nigeria, 16(1), $227-233$.

Adegoke, G.T. (2010). Socio-cultural Factors as a Determinant of Divorce Rate among Women of Reproductive Age in Ibadan metropolis, Nigeria. Journal of Study Tribal, $8(2), 107-114$

Ahiaoma, I. (2013). The Psycho-Social Effect of Parental Separation and Divorce on Adolescents: Implications for Counselling in Surulere LGA of Lagos State, International Journal of Psychology and Counselling, 5(7), 162-168.

Akinlabi, F. B. \& Olatunji, F. B. (2013). Social, Economic and Educational Implications of Parental Separation on the Upbringing of School Children in Ekiti State, Nigeria, Global Advanced Research Journals of Peace, Gender and Development Studies, 2(2), 21-25.

Alami, A., Khosravan, S.,Moghadam, L. S., Pakravan, F \& Hosseini, F. (2014). Adolescent Self-Esteem in Single and Two-Parent Families NCBI-NIH (Electronic version), International Journal of Community based Nursing and Midwifery, 2(2), 69.

Alexander, T. (2001). Defining Self-Esteem: What is Self-Esteem and Why does it Matter? Self-esteem as an Aid to Understanding and Recovery, Mental healthcare, 4(10), 332-335.

Amato P R. (2010). Research on Divorce: Continuing Trends and New Developments, Journal of Marriage and Family, 72, 650-666.

Amato, P. R. (2001). Children of Divorce in the 1990s: An Update of the Amato and Keith (1991) Meta-analysis (Electronic version), Journal of Family Psychology, 15(3), 355-370.

Baker, A. J. L \& Ben-Ami, N. (2011). To Turn a Child against a Parent is to Turn a Child against himself: The Direct and Indirect Effects of Exposure to Parental Alienation Strategies on Self-Esteem and Well-being, Journal of Divorce and Remarriage, 52(7), 472-489.

Bing, N. M., Nelson, W. M\& Wesolowski, K. L. (2009).Comparing the Effects of the Amount of Conflict on Children's Adjustment Following Parental Divorce, Journal of Divorce \& Remarriage, 50 (3), 159-171.

Bleidorn, W., Arslan, R. C., Denissen, J. J. A., Rentfrow, P. J., Gebauer, J. E., Potter, J., \& Gosling, S. D. (2016). Age and Gender Differences in Self-esteem: A Cross-cultural Window. Journal of Personality and Social Psychology, 111(3), 396-410.

Bowlby, J. (1969/1982). Attachment and loss: Vol. 1. Attachment. New York: Basic Books. 
Bowlby, J. (1973). Attachment and loss: Vol. 2. Separation: Anxiety, and Anger. New York: Basic Books.

Bowlby, J. (1979). The making and breaking of affectional bonds. London: Tavistock/Routledge.

Bowlby, J. (1980) Attachment and Loss: vol. 3. Loss, Sadness and Depression. New york.

Branden, N. (1994). The psychology of self-esteem: A new concept of man's psychological nature. Los Angeles: Nash.

Cakici, D. (2010). The analysis of social efficacy and self-esteem levels of ninth and tenth grade sports and general high school students. Master's thesis, Mersin Universitesi, Mersin, Turkey.

California State Department of Education (1990). Toward a state of self-esteem: The final report of the California Taskforce to promote self-esteem and social responsibility. Sacramento, CA: Author.

Carmicheal, S. G., Dilli, S \& Zandan, J. L. V. (2016). Introduction to Family Systems and Economic Development, Developing Regions (Electronic version), 31(1), 1-9.

Cayer, N. J. (1996). Public Personnel Administration in the United States (3rd ed.). New York: Wadsworth.

Cevik, B. G \& Atici, M. (2009). An Investigation of the Third Graders' Self-esteem Characteristics regarding Some Variables, Uluslararası Insan Bilmileri Dergisi, 6(1), 339-352.

Chinawa, J. M., Obu, H.A., Manyike, P.C., Obi, I.E., Israel, O.O., Chinawa, A.T (2015). Self-esteem among Adolescents in Nigerian Secondary Schools: A Neglected Issue, British Journal of Medicine and Medical Research (Electronic version), 5(1), 98-106.

Chiu, L. H. (1988). Measures of Self-esteem for School Age Children, Journal of Counselling \& Development, 66(6), 298-301

Clarke-Stewart, K.A; Vandell, D. L; McCartney, K; Owen, M.T\& Booth, C. (2000) Effects of Parental Separation and Divorce on very Young Children, (Electronic version) Journal of Family Psychology, 14, 304-26.

Cohen, P; Kasen, S; Chen, H; Hartmark, C. \& Gordon, K. (2003). Variations in Patterns of Developmental Transition in Emerging Adulthood, .Developmental Psychology, 9(4), 657-669.

Coopersmith, S. (1984) Self-esteem inventories. Palo Alto CA: Consulting Psychologists. Defining sexual health during adolescence. Retrieved June 6th, 2016 from

http://www.who.int/reproductivehealth/topics/sexualhealth/shdefinitions/en/index.html 
Dennis, U. D \& Oluwatelure, F.A. (2016). Self-esteem and Extroversion as Predictors of Clinical Leadership Competency among Clinicians in Nigeria, Clinical and Experimental Psychology (Electronic version), 2(122) doi:10:4172/24712701.1000122.

Egwurugwu, J.N., Ohamaeme, M.C., Dike, E.I., Chinko, B.C., Egwurugwu, E.NA \& Ohamaeme, C.R (2017). Assessment of Socio-demographic Factors and Self-esteem among Imo State University Medical Students, Nigeria. Journal of Advances in Medicine and Medical Research (Electronic version), 24(4), 1-12.

Elion, A. A., Wang, K. T., Slaney, R. B. \& French, B. H. (2012). Perfectionism in African American Students: Relationship to Racial Identity, GPA, Self-esteem and Depression, Cultural Diversity and Ethnic Minority Psychology, 18(2), 118-127

Feeney, B. C 7 Monin, J. K. (2008). An attachment-Theoretical perspective on divorce. Handbook of Attachment ( $2^{\text {nd }}$ Ed.). In J. Cassidy and P R Shaver (Ed.). Theory, Research and Clinical Applications. New York: Guilford Press.

Gelbal, S., Duyan, V., Servin, C. \& Erbay, E. (2010). Assessment of the Relationship between Socio-Demographic Characteristics and Situation of Social Support and Level of Self-esteem of High School Students. Toplum ve sosyal Hizmet, 21(2), 7-18.

Gonzalez-Mena, J. (1993). The child in the family and the community. New York: Classic Publishers Ltd.

Gray-Little, B., William, V. S \& Hancock, T. D. (1997). An Item Response Theory Analysis of the Rosenberg Self-Esteem Scale. Personality and Social Psychology Bulletin, 23(5), 443-451.

Hetherington, M. E. (2003). Social support and the adjustment of children in divorced and remarried families.SAGE Publications. London: Thousand Oaks and New Delhi, 10(2), 217-236.

Hudson, B. K. (2014). Sex Preferences, Marital Dissolution, and the Economic Status of Women, Journal of Human Resources, 40(2), 411-434.

Huitt, W. (2011). Self and self-views. Educational Psychology Interactive. Valdosta, GA: Valdosta state university. Retrieved [March 2016], from http://www.edpsycinteractive.org/topics/self/self.html humanities, 13th Edition.

Irvin, M. (2012). 32 shocking divorce statistics. Retrieved on 27th of April 2017 from http://www.Mckinleyirvin.com/Family_Law-Blog/2012/October/32-shocking-divorcestatistics.aspx

kahyaoglu, S. (2010). Relative effects of perceived social support from family and perceived social support from friends on adolescents' self-esteem (Master's thesis) Istanbul Bilgi Universites, Istanbul, Turkey. 
Karatas, Z. (2012) An Investigation of Self-esteem Levels and Empathic Skills of Educational Faculty Students, Mehmet Akif Ersoy University Journal of Education Faculty, 1(23), 97-114.

Kevorkian, C (2010). Father absence and self-esteem amongst economically disadvantaged children. Providence, Rhode Island Providence college:55 available at http://digitalcommons.providence.edu/socialwrk_students/55

Kithela, S. M. (2016) Relationships among school type and secondary school students' self-esteem, academic achievement and career aspirations in Nairobi County, Kenya. Published doctoral dissertation, Kenyatta University, Kenya. Retrieved on 27th April 2017 from http://ir-library.ku.ac.ke/handle/123456789/318

Kolander, C.A, Ballard, D, \& Chandler, C.K. (2009).Contemporary Women's Health: Issues for today and the future. St. Louis: WCB/McGraw Hill Higher Education.

Lansford, J.E. (2009). Parental Divorce and Child Adjustment, Perspectives on Psychological Science, 4, 140-152.

Laoye-Balogun, A. (2015) The evolution of divorce law and practice in Nigeria. Retrieved on 27th of April 2017 from http://www.linkedin.com/evolution-divorce-lawpractice-nigeria-abimbola-laoye

Marks, N. F, Jun, H., Song, J (2007) Death of Parents and Adult Psychological and Physical Well-being: A Prospective U. S. National Study, Journal of Family Issues, 28, 1611-38.

Martin-Albo, J., Nunez, J. L., Navarro, J. G., Grijalvo, F. (2007). The Rosenberg SelfEsteem Scale: Translation and Validation in University students, The Spanish Journal of Psychology, 10(2), 458-467.

Mekonen, H. (2014). The effects of divorce on adolescents' self-esteem: the case of adolescents at Federal first instance court. Published masters' Thesis, Addis Ababa University, Ethiopia.

Moschion, J. (2015). Do Childhood Experiences of Parental Separation Lead to Homelessness? EconomiX, Journal of Melbourne Institute of Applied Economic and Social Research, University of Melbourne,moschion@unimelb.edu.au.Retrieved on 11th of April $\quad 2017$ from http://marroninstitute.nyu.edu/uploads/content/Moschion__vanOurs_(2015).pdf

Mullen, J. (2013). Can family composition influence self-esteem, altruism, parental and peer attachment and views of marriage? Retrieved on $16^{\text {th }}$ June 2018 from https://esource.dbs.ie/handie/10788//614

Nugent, P.M.S. (2013) Marriage. Retrieved on the $14^{\text {th }}$ June 2018 from https//psychologydictionary.org/marriage 
Okwaraji, F.E., Aguwa, E.N., \& Shiweobi-Eze, C. (2016). Life Satisfaction, Self-esteem and Depression in a Sample of Nigerian Adolescents, International Neuro- Psychiatric Disease Journal (Electronic version), 5(3), 1-8

Olayinka, M.S \& Omoegun, O.M (2002). Principles and practice of guidance and counselling. Ikorodu:Bad Sheriff \& CO Limited.

Oner-Altiok, H., Ek, N. \& Koruklu, N. (2010). Investigating the Variables Related with Self-esteem of the University Students, Adnan Menderes Universitesi Egitim Fakiiltesi Egitim Pilimleri Dergisi, 1(1), 99-120.

Oniye, A.O. (2016). Marital and Family Counselling in A.I. Idowu (Ed.) Guidance and Counselling in Education. 249-268 Ilorin: Unilorin Press.

Orth, U. \& Robins, R. W. (2014). The Development of Self-esteem, Current Directions in Psychological Science, 23, 381-387. http://dx.doi .org/10.1177/0963721414547414

Oyinloye, O.A. (2001). Strategies for coping with disruptive behaviour in in-school adolescents in Okonkwo, R.U.N\&Okoye, R.O. (Ed.).The Nigerian Adolescents in Perspective. .Awka: Theo Onwuka and sons publishers.

Page, T., \& Bretherton, I. (2001). Mother-and-father-child Attachment Themes in the Story Completions of Pre-schoolers from Post-divorce Families: Do They Predict Relationships with Peers and Teachers?, Attachment and Human Development, 3, 129.

Pullmann, H., \& Allik, J. (2000). The Rosenberg Self-Esteem Scale: Its Dimensionality, Stability and Personality Correlates in Estonian, Personality and Individual Differences, 28, 701-715.

Rosnati, R., Daniela, B \& Daniela, U. (2014). Adolescents and Parental Separation or Divorce: The Protective Role of Values against Transgressive Behaviour, ProcediaSocial and Behavioural Sciences (Electronic version), 140, 186-191.

Ross, L. T. \& Miller, J. R. (2009). Parental Divorce and College Students: The Impact of Family Unpredictability and Perceptions of Divorce, Journal of Divorce and Remarriage,50(4), 248-259.

Secer, I., Ilbay, B. A., Ay, I \& Ciftc, M. (2012). Investigating the Self-esteem of Elementary Boarding School Students, Sakarya Journal of Education, 3(1), 1-17.

Sentse, M; Ormel, J; Veenstra, R; Verhulst, F. C \& Oldehinkel, A. J. (2011) Temperament Moderates the Impact of Parental Separation on Adolescents Mental Health (Electronic version), Journal of Family Psychology, 25, 97-106.

Sherman, A. R. (2015). Characteristics of high and low self-esteem. Retrieved on 27th April 2017 from www.https://Psychskills.com

Sirvanli-Ozen, D. (2005). Impacts of Divorce on the Behaviour and Adjustment Problems, Parenting Styles and Attachment Styles of Children: Literature Review including Turkish Studies, Journal of Divorce and Remarriage, 42, 127-151. 
Short, J. L. (2002). The Effects of Parental Divorce during Childhood on College Students, Journal of Divorce \& Remarriage, 38(1-2), 143-156.

Sternke, J. C. (2010). Self-concept and self-esteem in adolescents with learning disabilities. Published master'sthesis, University of Wisconsin-Stout.

Veenstra R, Lindenberg S, OldenhinkelA..J, DeWinter, A..F, Ormel, J. (2006). Temperament, Environment and Antisocial Behaviour in a Population Sample of Preadolescent Boys and Girls, International Journal of Behavioural Development, 30, 422-432.

Watkins, D; Dong, Q \& Xia, Y. (1997). Age and Gender Differences in the Self-esteem of Chinese Children, Journal of Social Psychology, 137(3), 374-379.

Wilson, L. (2013). The family unit and its importance. Retrieved on $16^{\text {th }}$ of June 2018 from https://dr/wilson.com/Articles/FAMILIEShtm 